\title{
The Elements of Fold Style Analysis in the Khaftar Anticline, Zagros, Iran
}

\author{
Zahra Maleki1*, Mehran Arian1, Ali Solgi', Mohammad Ali Ganjavian² \\ ${ }^{1}$ Department of Geology, College of Basic Sciences, Tehran Science and Research Branch, Islamic Azad \\ University, Tehran, Iran \\ ${ }^{2}$ Department of Geology, Shahrood Branch, Islamic Azad University, Shahrood, Iran \\ Email: ${ }^{*}$ z.maleki@srbiau.ac.ir
}

Received 24 January 2014; revised 20 February 2014; accepted 27 February 2014

Copyright $@ 2014$ by authors and Scientific Research Publishing Inc.

This work is licensed under the Creative Commons Attribution International License (CC BY). http://creativecommons.org/licenses/by/4.0/

\section{Open Access}

\section{Abstract}

The Study area is located in the Zagros Simply Folded Belt of Iran and in the interior Fars sub-basin. The Khaftar anticline is located in the West, North-West of Jahrom city in the Fars province (148 km distance from Persian Gulf). The trend of Khaftar anticline has three orientations, consist of North- Northeast, East-West and South- Southwest. This anticline has asymmetric structure and some faults with large strike separation observed in this anticline. In the study area, stratigraphic units are affected by many faults in this area. Also one salt plug cropping out in the middle part of the Khaftar anticline. Maybe this salt plug affected on the stratigraphic units and geometry of structure. Description of fold geometry is important because it allows comparisons within and between folds and allow us to recognize patterns in the occurrence and distribution of fold systems. The main aim of this paper is determination of fold style elements and folding pattern of the Khaftar anticline. This paper presents a part of the results of a regional study of the Fars province in the Zagros Simply folded belt, based on satellite images, geological maps, and well data. Some data, such as geological maps and geological regional data were prepared and provided by the National Iranian Oil Company (NIOC). Because of the Khaftar anticline, has complex structure, the analysis of fold style elements is seems necessary. Therefore, in further studies on this structure the changes of fold style elements will be analyzed and investigated from east to west in the different parts of this anticline. The activity of Nezamabad sinistral strike slip fault in the Khaftar anticline causes changes of axial plane characteristics and fold axis. Some of the results such as folding style analysis, how position of salt plug, changes of fold type and main structural changes (rotation of fold axis and $2.5 \mathrm{~km}$ displacement in this anticline) show main changes in the middle parts of the Khaftar anticline. It seems that, these changes have formed by activity of the Nezamabad fault and this fault's activity same as fault zone.

\footnotetext{
*Corresponding author.
} 


\section{Keywords}

\section{Zagros; Iran; The Khaftar Anticline; Fold Style Elements; Nezamabad Fault}

\section{Introduction}

The study area is located in the Zagros Simply Folded Belt of Iran and in the interior Fars sub-basin [1] [2] (Figure 1). The Zagros Fold-thrust belt is home to one of the largest petroleum producing reservoirs in the world [3]. This belt is recognized by the NW-SE trending parallel anticlines that verge to the SW in a $6-12 \mathrm{~km}$ cover sequence [3] [4]. The Simply Folded Zone (SFZ) is orientation as the southwesterly boundary of the Zagros orogen near the Persian Gulf.

Based on Physiographic-tectonic zoning map of Iran's (sedimentary basins of Iran), the study area is located in the Zagros-East Taurus hinterland [5] (Figure 2). In this region, the folds are capped by the Oligocene Asmari

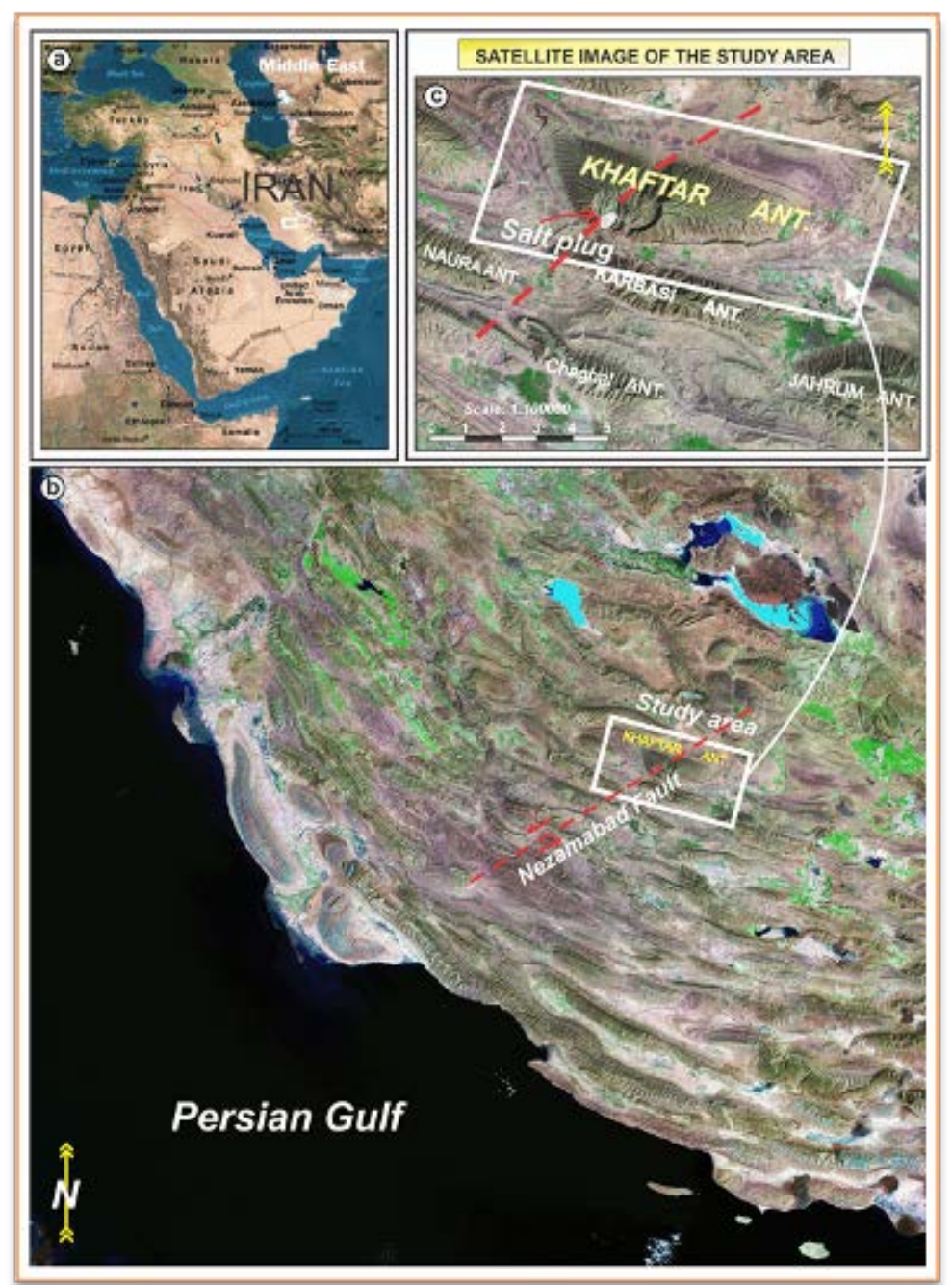

Figure 1. Landsat Satellite image showing the study area and location of the Khaftar anticline in the Zagros fold-thrust belt, southern of Iran. Inset Satellite image (a) shows location of the study area with white framework in the Middle East. Also, in this figure shows location of the Khaftar salt plug in the study area. 


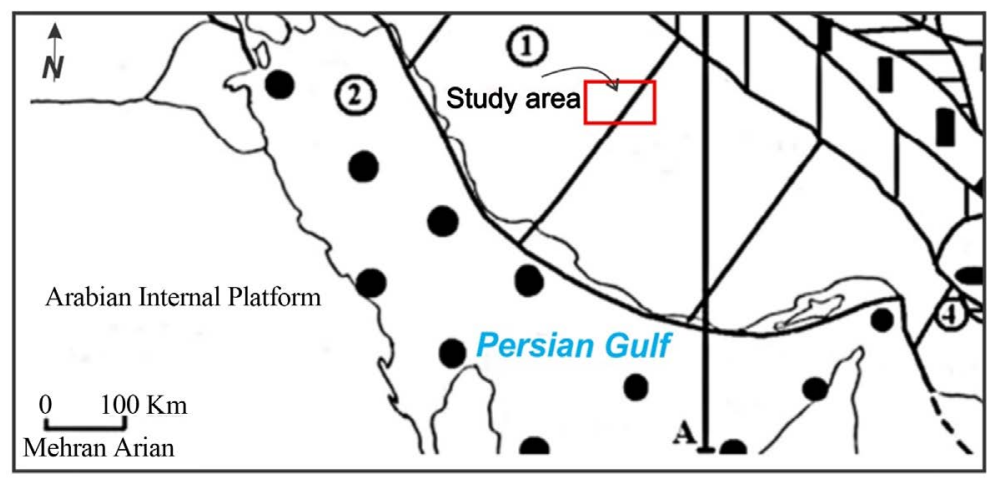

Figure 2. Physiographic-tectonic zoning map of Iran's sedimentary basins Iran showing the study area in the Zagros-East Taurus hinterland [5]

Limestone [3] [6] [7] and the sedimentary cover sequence is floored by the Hormuz Formation, a dominantly evaporate formation, which acts as a major decollement horizon [8]-[10].

In this area, the Khaftar anticline has asymmetric structure and some faults such as the Nezama bad fault effect on this anticline. This structure is located in the West, North -West Jahrom city in the Fars province (148 $\mathrm{km}$ from Persian Gulf). Structures in this area have complications and the study area has complex structure in the Fars region.

The geometry of anticlines in the Zagros fold-thrust belt are affected by type of deformation and mechanical behavior of stratigraphic units specially detachment units [11]. In this belt, detachment units are important for controlled folding pattern [12] [13]. The basal Hormuz and other detachments play important roles for the style of the Zagros Fold-thrust belt structures. One of the main detachment units in the study area is Dashtak formation that belongs to Kazeron group. This formation is composed of evaporate, shale and dolomite units. This formation has important role on folding geometry especially in the Fars region. Also, other detachment formations in this area are Kazdomi and Gachsaran formations that play important roles on the structural style of area.

In the Zagros fold-thrust belt, structural analysis of surface and subsurface data shows that salt layers such as Cambrian Hormuz and the Miocene Gasharan have direct control on the structural style [14]. Until now, In the Zagros fold-thrust belt, many studies have been done on to variation of structural style and effects of detachment folding on folding pattern [12] [13]. Also, many researchers discussed basement involvement and reactivated structures in the Zagros fold-thrust belt and its roll on folding pattern, e.g. [10] [15]-[18]. Several researchers, such as Kashfi (1972), Falkon (1969), Alavi (1994), Letouzey (2005) and Sherkati et al., (2005), emphasized the role of mechanical stratigraphy on the structural style as in above-mentioned.

For the first time, Stearns (1978) introduced concept of mechanical lithology in this area and O’Brien (1950) [19] was the first one to show the effects of detachment layers on folding process and other researchers have discussed about this too, e.g. [20]-[23].

In the Fars region, the Khaftar Anticline possesses Specific structures. This anticline has complex structure and in the middle of anticline, cropping out Salt plug nears the southern limb. This anticline is located in the West, North-West Jahrom city in the Fars province (148 km distance from Persian Gulf) (Figures 1 and 3). Structures in this area have complications and the oldest stratigraphy unit that outcropped in the Khaftar anticline on the surface belongs to Hormuz Series. The age of oldest rock unit is Pre-Cambrian-Cambrian.

The first geological report on the Khaftar anticline dates back to the 1974 by the National Iranian Oil Company (NIOC) and SOFIRAN EGOCO (Exploration Company). Some researchers just briefly study on this region and introduced the Khaftar anticline as a cutted fold by the Nezama bad strike slip fault [25] [26].

Description of fold geometry is important because they allow comparisons within and between folds and pattern-recognition in addition to occurrence and distribution of fold systems. The main aim of this paper is to determine of fold style elements and folding pattern of the Khaftar anticline.

\section{Material and Methods}

This paper presents part of the results of a regional study of the Fars province in the Zagros Simply folded belt, 


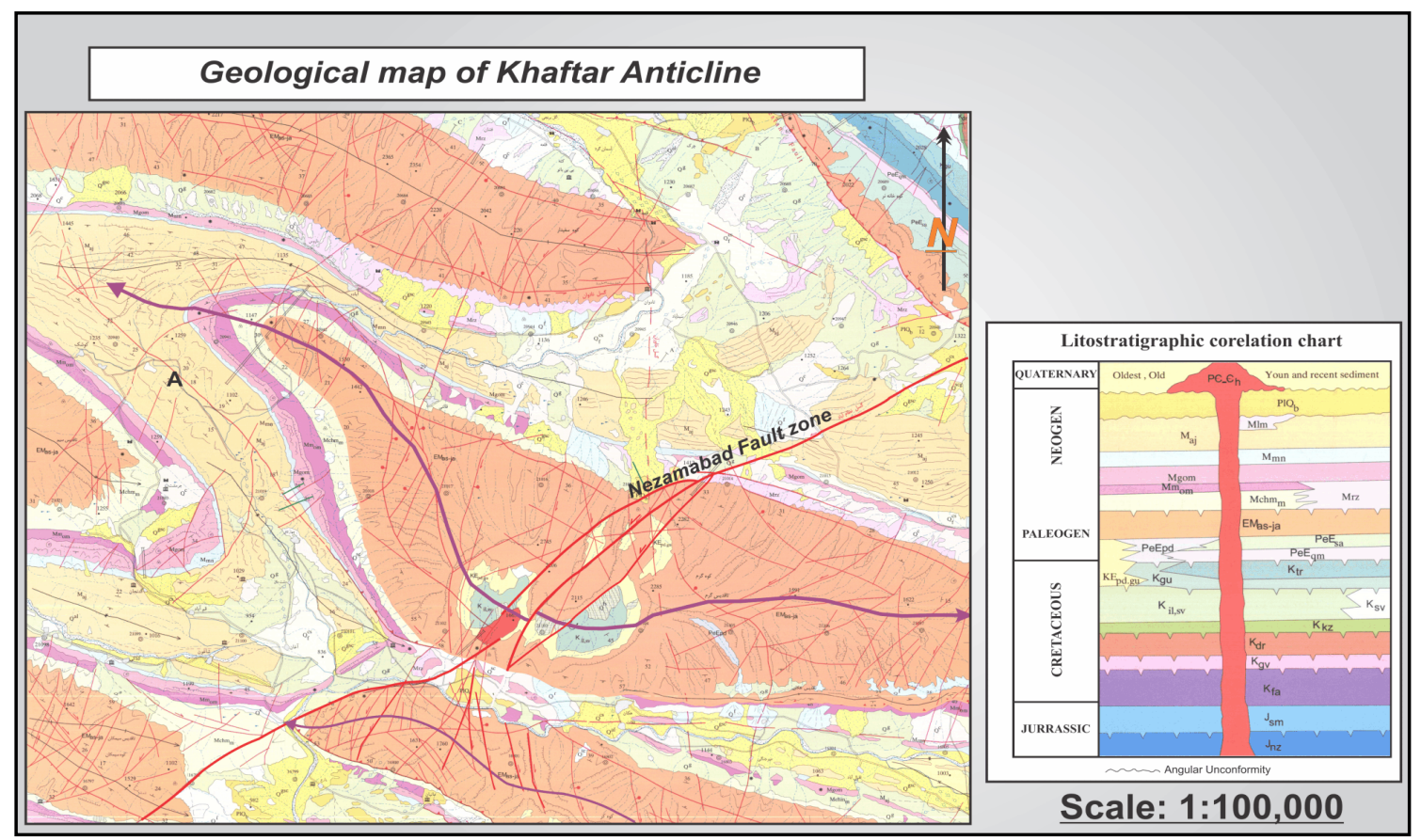

Figure 3. Geological map of Khaftar anticline. In this map shows the position of salt plug that exposed in the middle part of anticline. Modifiedafter [24].

based on original fieldwork, satellite images, thin sections, geological maps and well data. Our fieldwork in the study area and some data such as geological maps and geological regional data were prepared and provided by the National Iranian Oil Company (NIOC). In the study area, not provided seismic data to analysis and discuss the structural features by Oil Companies in this region. All geological reports have studied and all the elements of fold style have calculated and analyzed. We used fold style elements analysis methods (description of folds) based on [27]-[30]. We used Tectonics FP software for prepared and analyzed Stereo plots of the Khaftar anticline. Also, we used Global Mapper Software for prepared 3D SRTM of the study area and 3D Path Profile (along cross sections) based on Global Mapper Software. 3D SRTM prepared based on Digital Elevation Model (DEM) and geological map of study area (in scale 1:100,000, 1:250,000 and 1:1000,000 — published by the National Oil Company and the Geological Survey of Iran).

\section{Geological Setting and Stratigraphy}

In this paper, the Study area is located in the Zagros orogenic belt. The Zagros fold and thrust belt was formed by collision of two tectonic plates the Eurasian or Iranian and Arabian Plates. In this belt, the Fars region, on the basis of geological fancies units perpendicular to Zagros belt was divided into the interior Fars, coastal Fars and sub-coastal Fars sub-basins [1] [2] and the study area is located in the Interior Fars sub-basin. This area is easily recognized by the NW-SE orientation parallel anticlines that verge to the SW in a 6 - $12 \mathrm{~km}$ cover sequence [3] [31].

In the Zagros fold-trust belt, the oldest known stratigraphic unit with 2000 - 1000 meters thickness estimated as Hormuz Series [32]-[34] and is exposed in the form of salt domes in the Fars region. Structures in this area have complications and the oldest stratigraphy unit that outcropped in the Khaftar anticline on the surface belongs to Hormuz Series (salt plug). The age of Hormuz Series is Pre- Cambrian- Cambrian (Figure 4).

Anticlines outcropping stratigraphic units in the most of structures Fars region often include Upper Cretaceous stratigraphic units (MaesTryshtyn-Campanian to the present) and in the sub-coastal Fars region, includes the Lower Cretaceous stratigraphic units (Neocomian to the present). The youngest formations that outcrop in the study area are Aghajari and Bakhtiari and Razak formations. Also, in the interior Fars sub-basin, the oldest outcrops is Hormuz Series observed in the Khaftar, Kuh-e Qazi and Surmeh anticlines form of salt domes [1] [2] [36]. 


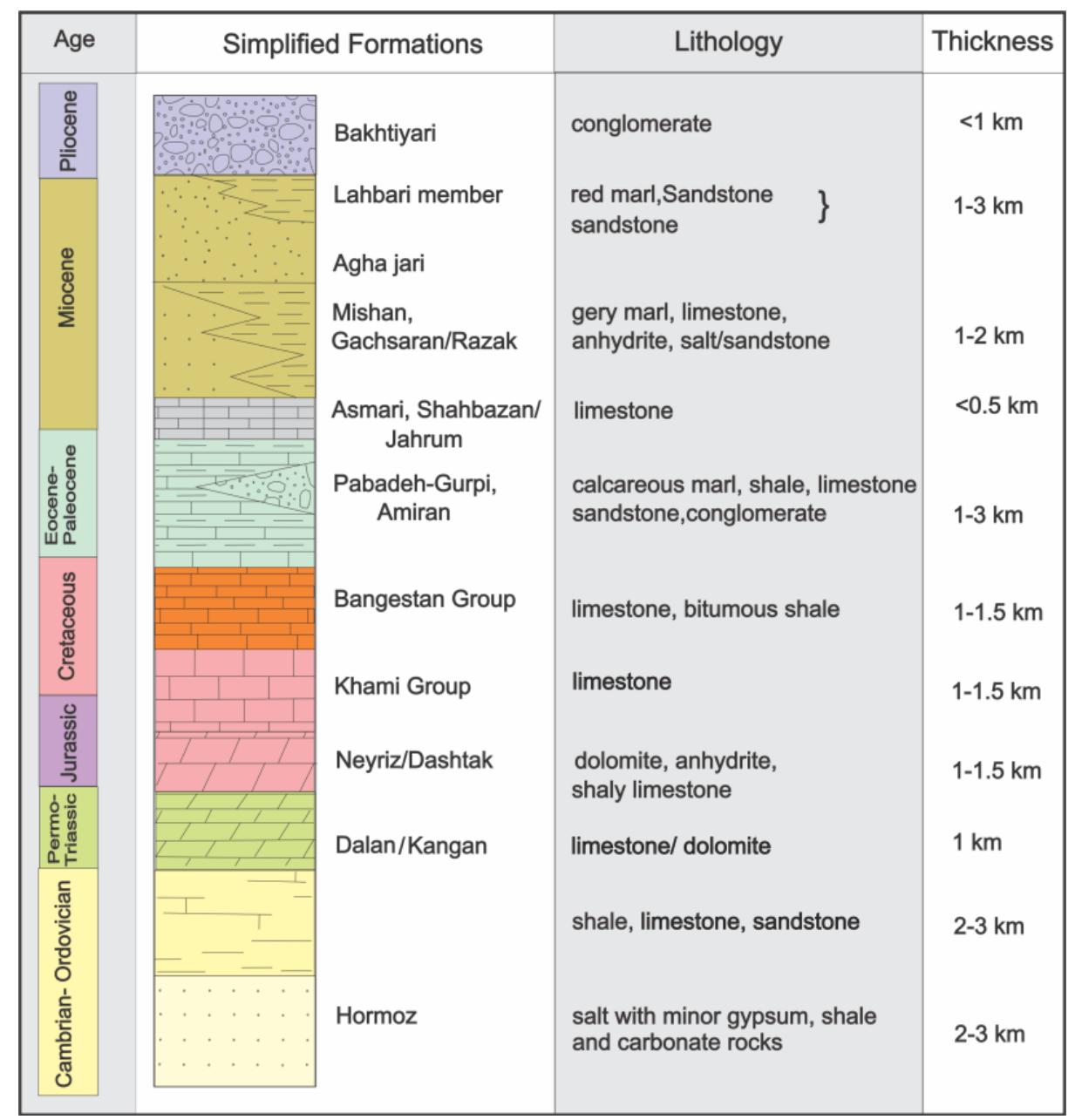

Figure 4. Generalised stratigraphic column through the Zagros fold-thrust belt. (Modified after [35]).

The Khaftar anticline is located in the West, North -West of the Jahrom city in the Fars province (148 km to Persian Gulf). This anticline has three orientations that consist of North- Northeast, East-West and SouthSouthwest. This anticline is bounded from north by the Kuh-e Qazi anticline, from north-northeast by the Qutba bad anticline, from south-southeast by the Karbasi anticline and from southwest by the Sim anticline (Figure 5).

The Khaftar anticline is an asymmetric structure, which has $45 \mathrm{~km}$ length and $12.5 \mathrm{~km}$ width in the Asmari horizon on the surface (Figure 3). The Mund River is flows in northern-southern path in this area and in the north-northwest parts of anticline; this river has flow changes in this of path. By whirling this river in the western part of anticline finally, the Mund River continues its path to south of the study area.

Based on Setchell et al. (2007), the Khaftar anticline is detachment fold and in the middle part of southern flank of the Khaftar anticline, cropping out salt plug (Figure 1). The most surface of anticline is generally covered with Asmari-Jahrom formation. This anticline is an asymmetrical anticline in which the dip of southern flank is greater than the northern flank (Figures 6 and 7). On the other hand, plunges dip value in western part of anticline more than eastern part.

The Coordinates of Khaftar salt plug (belongs to the Khaftar anticline) is located between $53^{\circ} 14^{\prime}$ to $53^{\circ} 18^{\prime}$ longitudes and $28^{\circ} 39^{\prime}$ to $28^{\circ} 41^{\prime}$ latitudes. Maximum length of the Khaftar salt plug is $3 \mathrm{~km}$ and Maximum width is $1.1 \mathrm{~km}$ (Figure 8). Based on satellite images, total Shape of salt plugs specially the satellite images is rhomboidal (NE-SW trending longer axis). It seems that the shape is influenced by complication of structural zone of the Nezamabad Fault zone with NE-SW direction. 


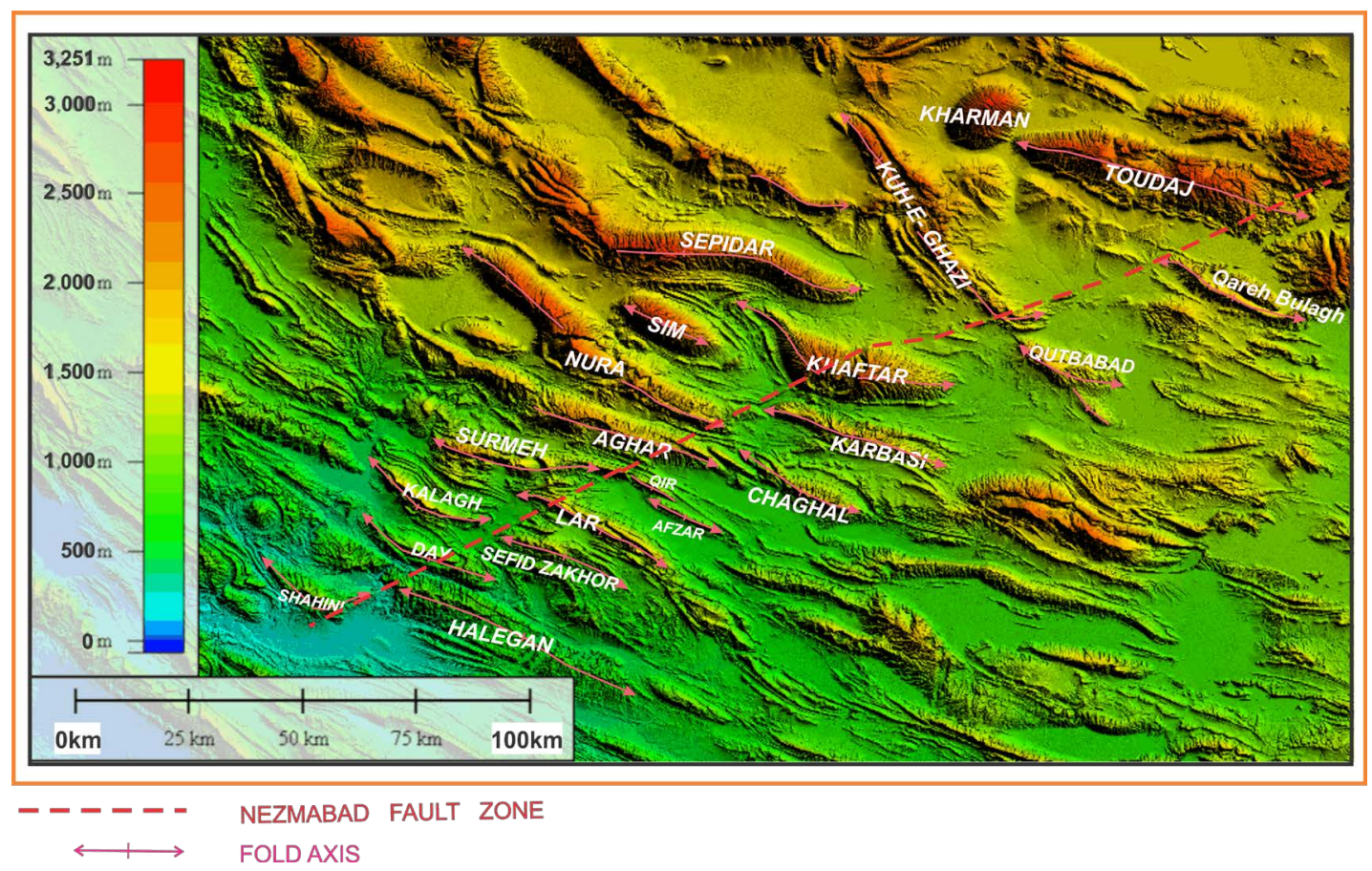

Figure 5. SRTM image (base on Digital Elevation Model (DEM)) showing the Khaftar anticline and adjacent anticlines in the Fars region.

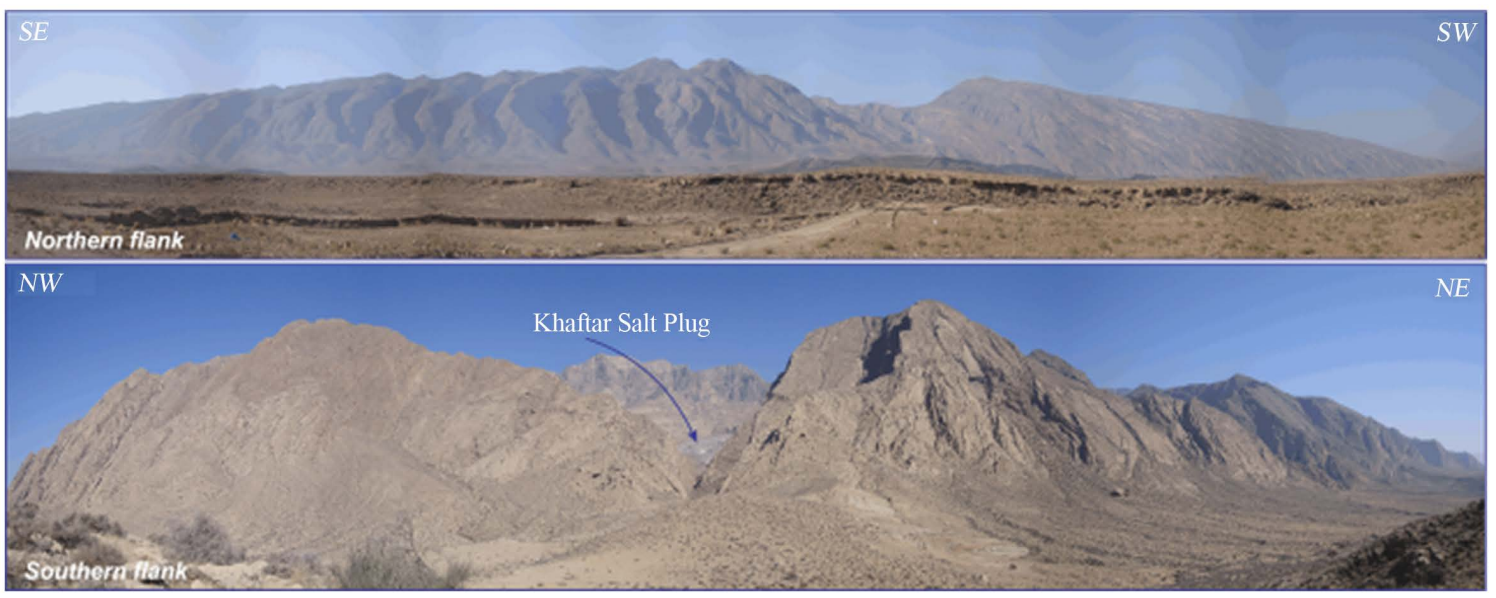

Figure 6. These photographs showing the panorama of northern and southern flank of the Khaftar anticline.

\section{Nezamabad Fault}

The Nezamabad fault is one of the strike slip fault with northeast- southwest trend in the Gavbandi High that divided this High from the Central Zagros [37]. The first time Barzegar (1994) introduced the Nezamabad fault based on satellite image. The Nezamabad fault is located between southern flank of the Shahini anticline and southeastern of Neyriz area [16] [25] [38]-[41] (Figure 5). The most displacement of the Nezamabad fault easily observe on the satellite image of the Khaftar anticline about $265 \mathrm{~km}$ sinistral displacement (Figures 1 and 5). Also, Based on 3D path profiles of the Khaftar anticline (Figure 9) and gave results; it seems that most of the changes are observed in the $\mathrm{D}$ and $\mathrm{E}$ 3D path profiles (location of these profiles is located along the cross sections $\mathrm{A}-\mathrm{A}$ ' to G-G' in the Figure 11). These profiles with most of changes are along the Nezamabad fault. It seems that, the activity of this fault in the middle part of the Khaftar anticline causes these changes and rotation of the Khaftar anticline plunge. 


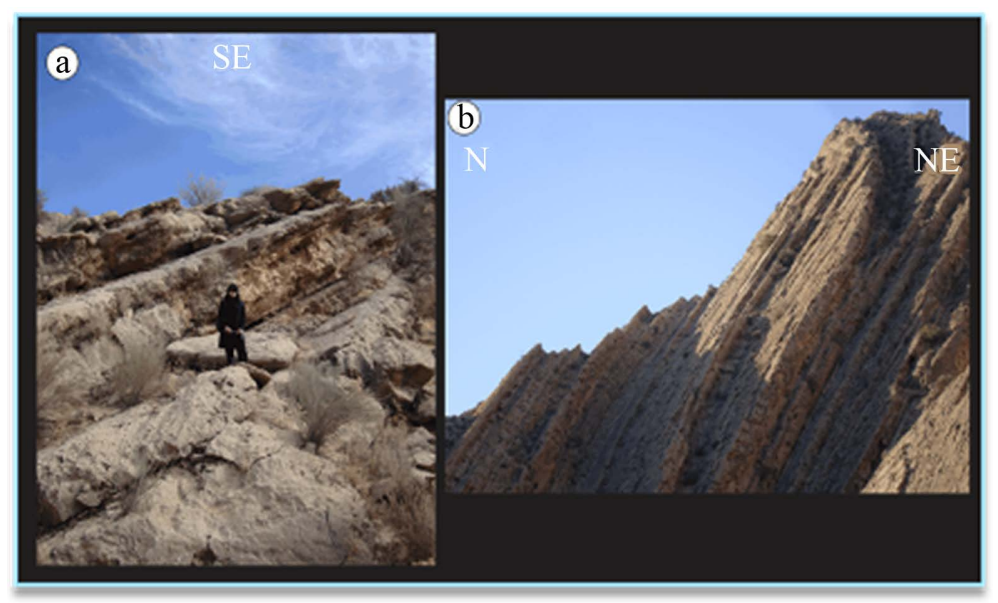

Figure 7. (a) Photograph and (b) showing the northern (a) and southern flank (b) of the Khaftar anticline. These photographs show the Asmari formation and dip value in the southern flank is greater than the northern flank.

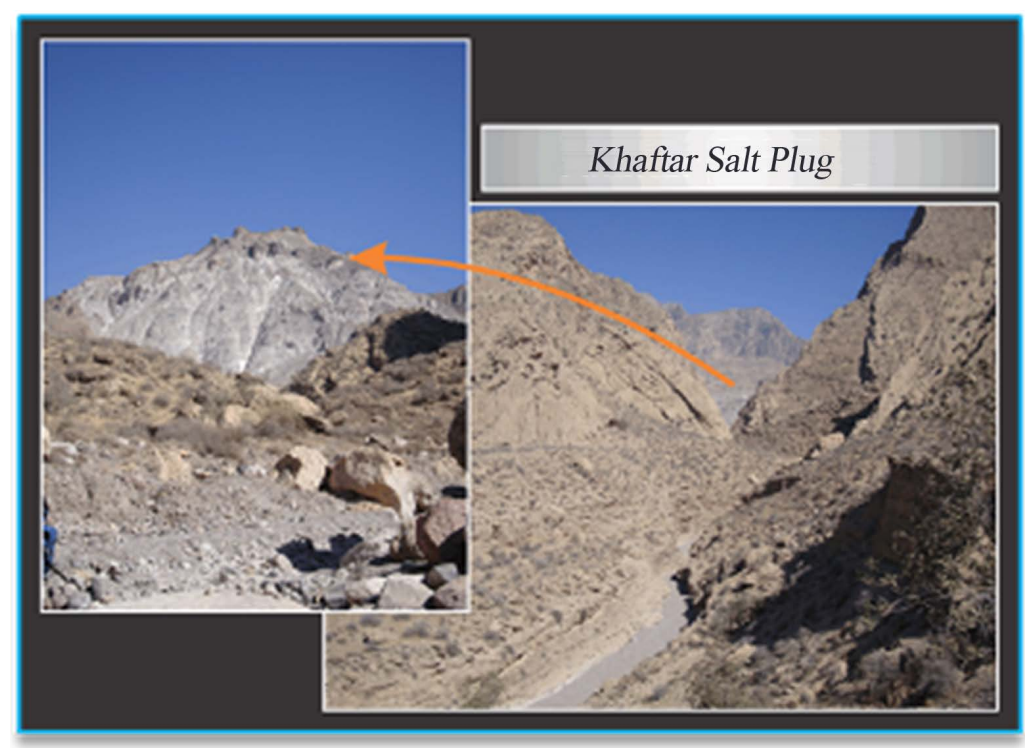

Figure 8. Photograph showing the location of salt plug (View to the northeast) in Southern flank of the Khaftar Anticline.

The numerous faults exist in the Khaftar anticline with different lengths and activities (Figure 10). Based on structural contour map (Figure 10) and our fieldwork, in the study area generally faults can be classified to two orders: major faults and minor faults. The Nezamabad sinistral strike slip fault is a major fault in the study area that specially affects on middle part of the Khaftar anticline. May be, cropping out of salt plug in middle part of the Khaftar anticline formed by the Nezamabad strike slip fault. In this area, the minor faults are located parallel with major fault and some of the minor faults are located parallel with fold axis (Figure 10).

\section{The Description of Folds}

Description of fold geometry is important because they allow comparisons within and between folds and allow us to recognize patterns in the occurrence and distribution of fold systems. For example, orogenic belts contain characteristic fold systems: along their flanks are large fold and thrust belts, with little metamorphism, but underlain by décollements; and in core zones where intense folding has accomplished, accompanied by high-grade metamorphism under high temperature and pressure. 

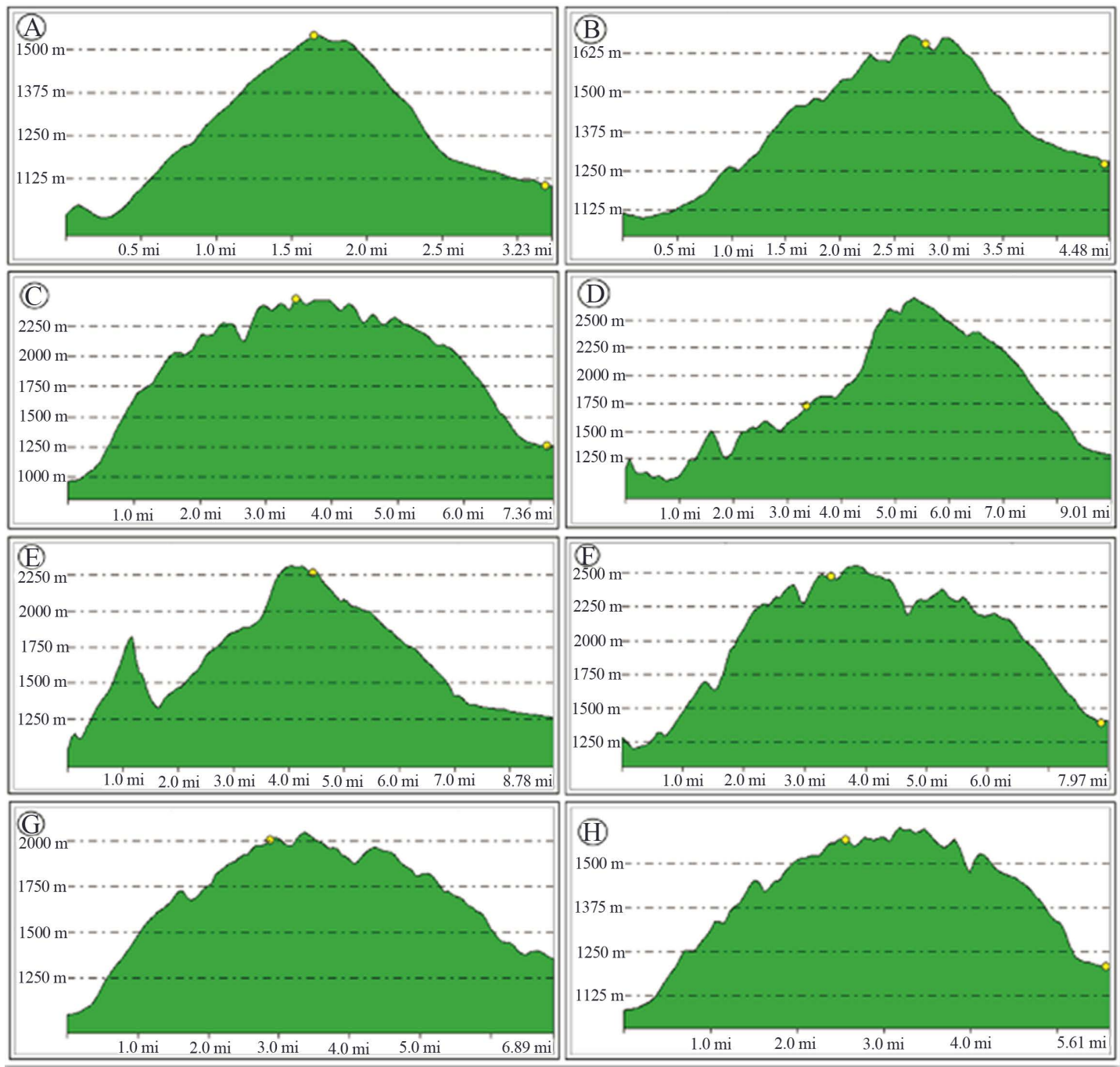

Figure 9. These diagrams showing 3D path profiles of the Khaftar anticline (location of these profiles is located along the cross sections A-A' to G-G' in the Figure 11). The horizontal axis and vertical axis showing distance (mile) and elevation (meter).

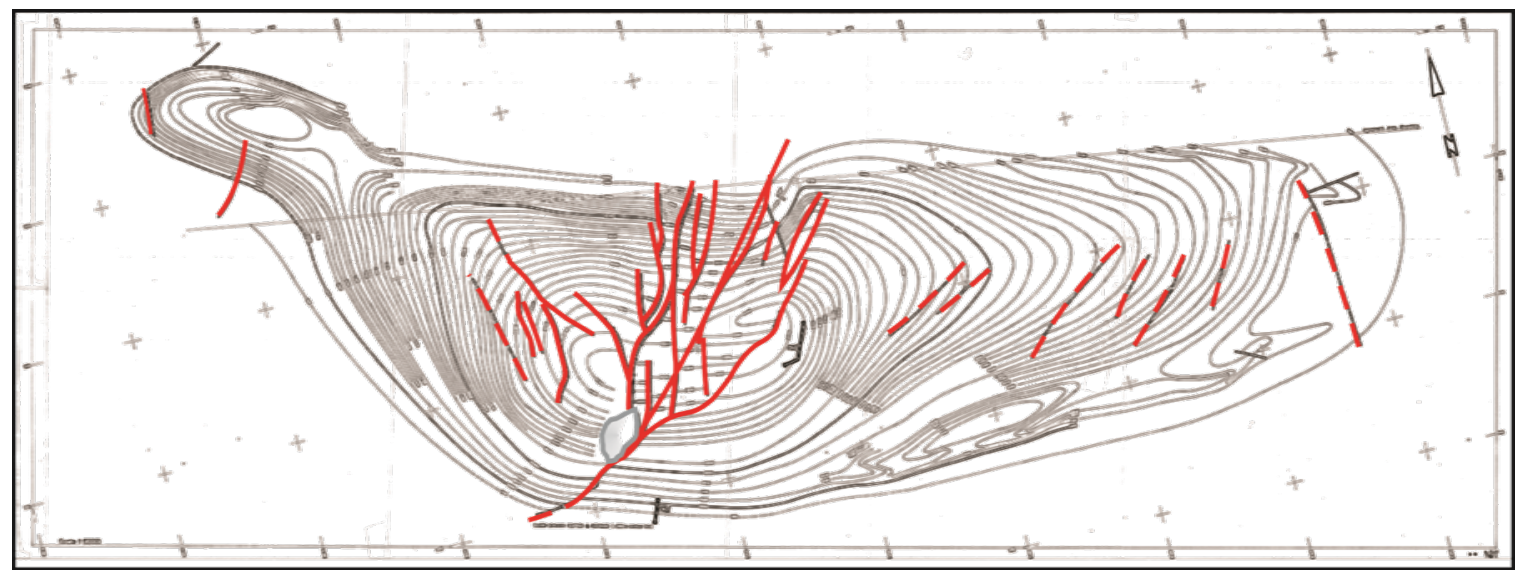

Figure 10. This map showing the structural contour map and many faults that exist in the Khaftar anticline (NIOCEGOCO Map, 1:50,000; Distance between contours is 50 meter). 


\section{Elements of Fold Style}

The style of a fold is the set of characteristic that describe its form. Over years of working with folds, geologists have identified certain features as particularly useful in describing fold and understanding how they develop [29].

Because the Khaftar anticline, has complex structure; the analysis of fold style elements is seems necessary. Therefore, for more studies on this structure the changes of fold style elements will be analyzed and investigated from east to west in the different parts of this anticline. Because of the Nezamabad fault effect on the middle parts of the Khaftar anticline, we have evaluated and calculated some elements of fold style, that measurable in this structure. In this respect, symmetry, cylindricity, Geometry of axial plane and Folding Mechanism have evaluated.

\subsection{Symmetry}

A folded surface forms a symmetric fold if in profile, the shape on one side of the hinge is a mirror image of the shape on the other side, and if adjacent limbs are identifiable in length [27]. The study anticline is an asymmetric fold with changed plunge in the north of the western part of fold. The Khaftar anticline is an asymmetric anticline. In the southern flank dip of layers is greater than the northern flank on the Asmari formation horizon (Figures 6 and 7). The Southern flank, layers have dip changes from about $60^{\circ}$ to $88^{\circ}$ and dip value in the northern flank ranges about $35^{\circ}$ to $50^{\circ}$.

\subsection{Cylindricity}

The Cylindricity is represented qualitatively on a stereonet by how closely the poles to planes around a fold fit a great circle distribution [27]. The studied anticline is a cylindrical to conical fold with changed plunge in the north of the western part of fold. The output of Tectonics FP software for seven parts of the Khaftar anticline is shown in the Figure 11.

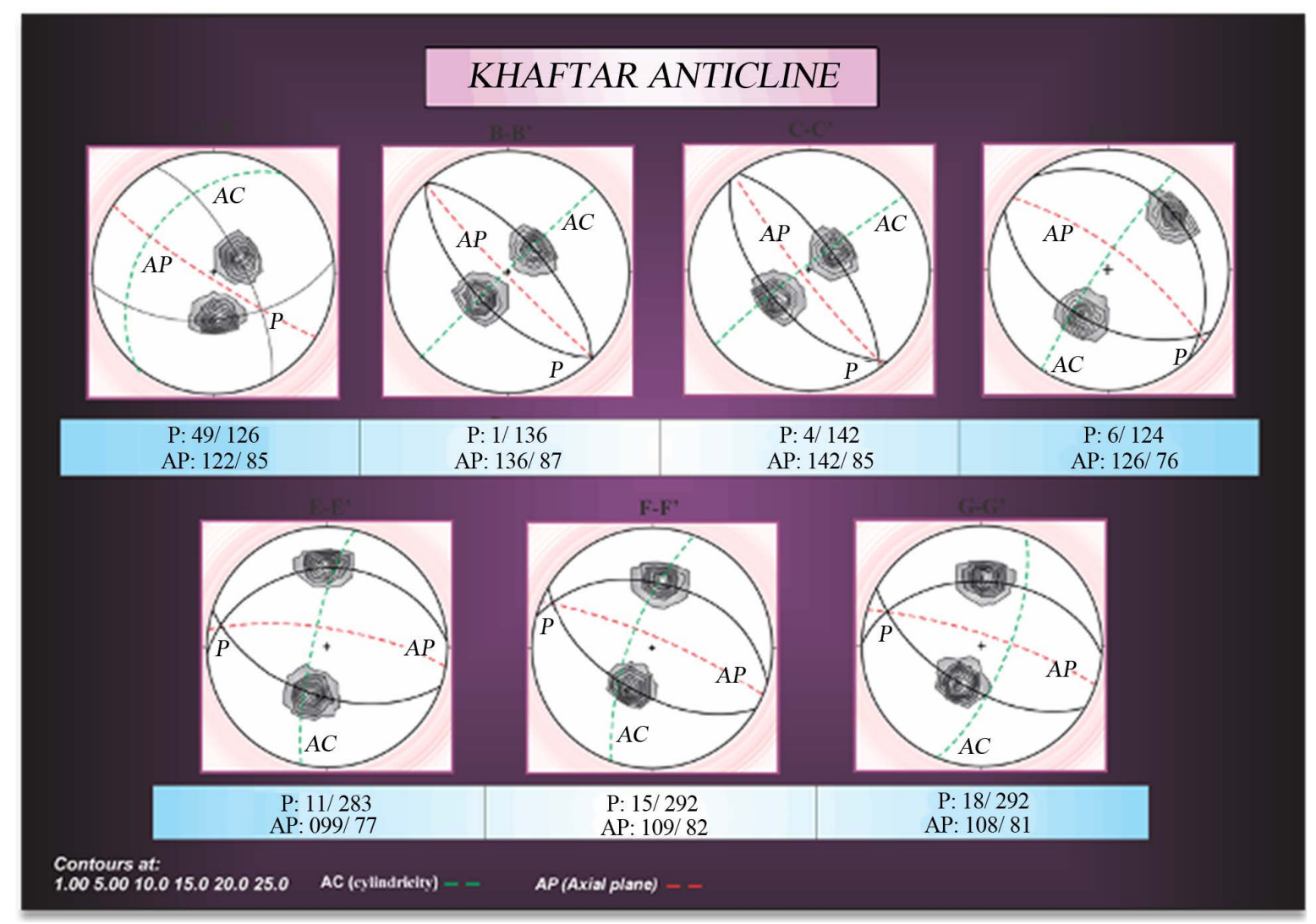

Figure 11. Stereoplots showing axial planes (AP), cylindricity (AC) for seven sections of the Khaftar anticline (based on [27]). 


\section{Classification of the Fold}

\subsection{Based on Geometry of Axial Plane}

Based on Twiss and Moors method (1992) for description of fold, seven stereoplots (output of Tectonics FP software) were prepared for seven parts of the Khaftar anticline. According to results, these stereoplots show the location of axial plane (AP) and cylindricity (AC) and Plunge of Fold (P) (Figure 12). This part to be done based on seven structural cross sections of the Khaftar anticline. The locations of these structural cross sections (from A-A' to G-G') is shown in the Figure 11.

According to description of fold [27] for seven sections in the Khaftar anticline (from A-A' to G-G'), the geometry of axial plane is planer. Also from A-A' to C-C', axial plane follow from one-pattern orientation of axial plane (dip of axial plane toward SW) and from D-D' to G-G' follows another pattern (dip of axial plane toward NE) (Figure 12). It seems that these changes (changes of orientation of axial plane from East to West in Khaftar anticline) affected by sinsitral displacement of Nezamabad fault. For more explanation, based on orientations of axial plane, see Figure 12. Change of dip of axial plane from NE (D-D' to G-G') to SW (A-A' to C-C') confirms sinistral displacement of Nezamabad fault and effect of this fault on the geometry of axial plane.

In the seven structural cross sections of the Khaftar anticline, dip value of axial plane is changing from $76^{\circ}$ to $87^{\circ}$. Based on classification of Ramsay (1967) for fold classification and changes of axial plane in different parts of anticline, the fold type in the D-D' and E-E' are different from other parts (Figure 13). Based on classification of

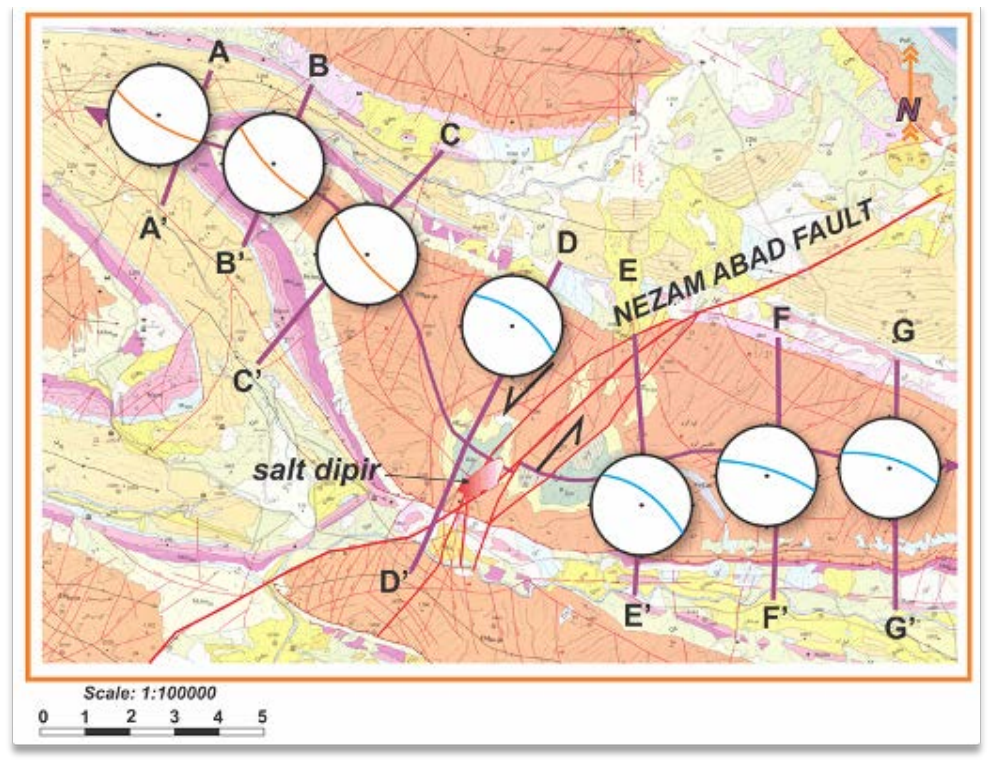

Figure 12. How located axial plane based on gave results in seven sections of Khaftar anticline, map scale 1:100000 [24].

\begin{tabular}{|c|c|c|c|c|c|c|c|}
\hline $\begin{array}{c}\text { Structural } \\
\text { cross sections }\end{array}$ & A-A' & B-B' & C-C' & D-D' & E-E' & F-F' & G-G' \\
\hline $\begin{array}{c}\text { Dip of axial } \\
\text { surface }\end{array}$ & $85^{\circ}$ & $87^{\circ}$ & $85^{\circ}$ & $76^{\circ}$ & $77^{\circ}$ & $82^{\circ}$ & $81^{\circ}$ \\
\hline $\begin{array}{c}\text { classification } \\
\text { of fold }\end{array}$ & upright & upright & upright & $\begin{array}{c}\text { Steeply } \\
\text { inclined }\end{array}$ & $\begin{array}{c}\text { Steeply } \\
\text { inclined }\end{array}$ & upright & upright \\
\hline
\end{tabular}

Figure 13. How located axial plane based on [29] gave results in seven sections of Khaftar anticline (Based on Ramsay, 1967). 
Ramsay (1967), in most parts of the Khaftar anticline, axial plane of fold is upright but in D-D' and E-E' sections axial plane is steeply inclined. May be sinistral displacement of the Nezamabad fault and cutted Khaftar anticline by this fault caused this change.

\subsection{Based on Folding Mechanism}

In this part, based on classification of Rickard (1971) and Ragan (1985),in the different parts of the Khaftar anticline, type of fold is variable and four types are recognize (Figures 14 and 15). In some parts of anticline as A-A', F-F' and G-G' sections, type of fold is moderately inclined moderately plunging. In the B-B' and C-C' sections, type of fold is upright horizontal. In the D-D' section type of fold is horizontal plunging and E-E' section type of fold is plunging fold. According to these results, because in some parts of fold dip value is less than other parts (D-D' and C-C') may be the Nezamabad fault affected on this case. Also based on classification of Ramsay (1967), in D-D' and E-E' sections axial plane is steeply inclined. The activity of the Nezama bad sinistral strike slip fault in the Khaftar anticline causes changes of axial plane characteristics and fold axis.

Based on the classification of Rickard (1971), in different parts of the Khaftar anticline, type of fold is different (Figure 15). In the eastern part of anticline (A-A' section) type of fold moderately inclined moderately plunging, so in the western part of anticline (G-G' section) type of fold is moderately inclined moderately plunging (Figure 15). Based on classification of Ramsay (1967) the orientation of fold in this anticline evaluated, for A-A' to G-G' profiles (Figure 16). Results show the orientation of fold in this anticline especially in the D-D' and E-E' parts are different than other parts. May be the Nezama bad fault has affected on the orientation of fold in these parts.

\section{Conclusions}

In the Khaftar anticline, activity of the Nezamabad sinistral strike slip fault has caused main changes on the fold style characteristics. According to give results of fold style elements analysis of the Khaftar anticline, it becomes clear that middle parts of the Khaftar anticline have affected by more deformation.

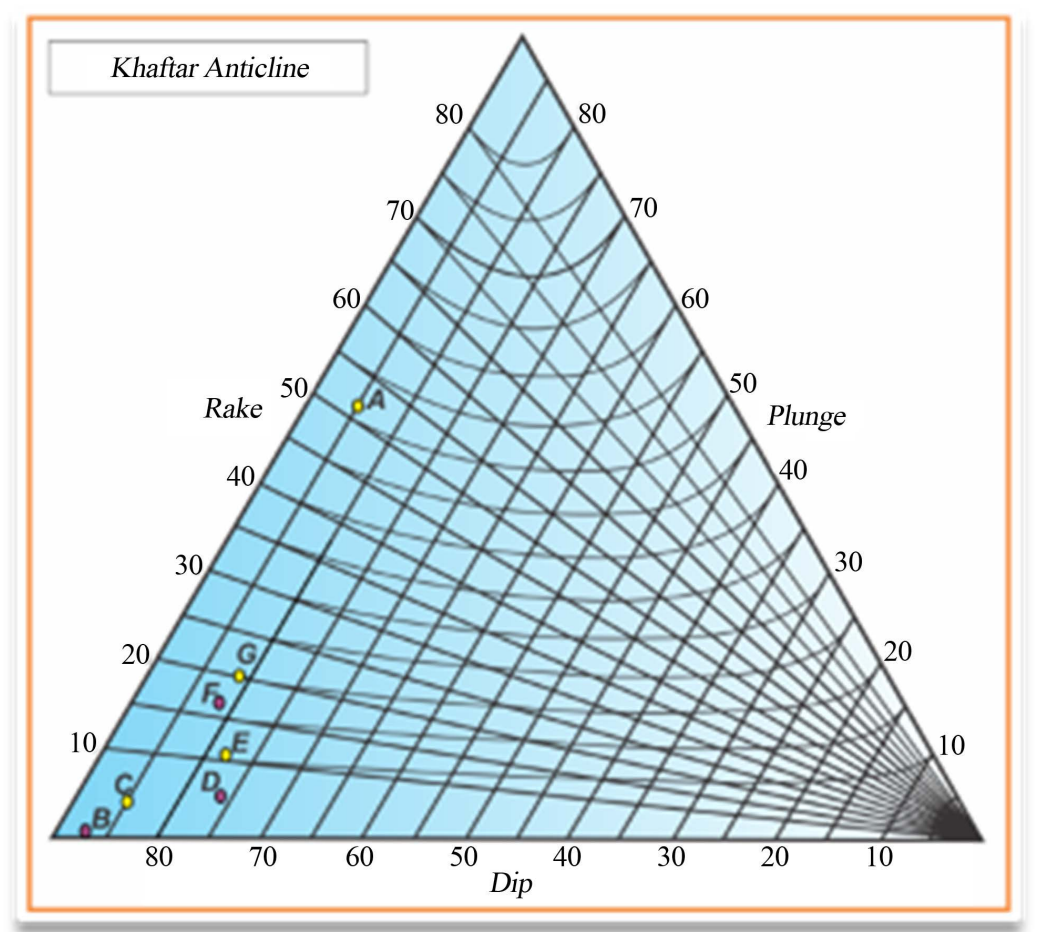

Figure 14. Triangle form Diagram showed type of fold in seven sections of Khaftar anticline, based on [30]. Type of fold in Part G (G-G' section) is different to other section completely. 


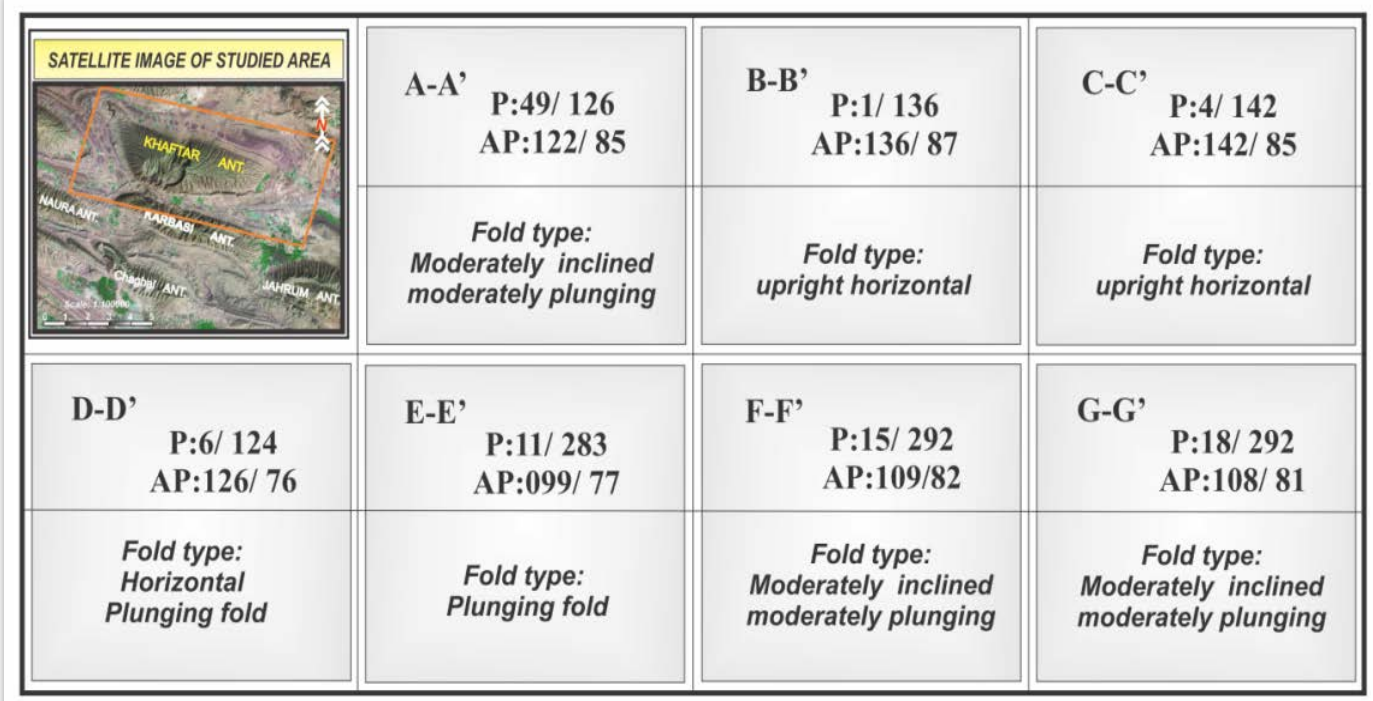

P: Plunge AP: Axial Plane

Figure 15. This table showing type of fold in seven sections of the Khaftar anticline. This classification based on [19] [28]-[30] [42] [43].

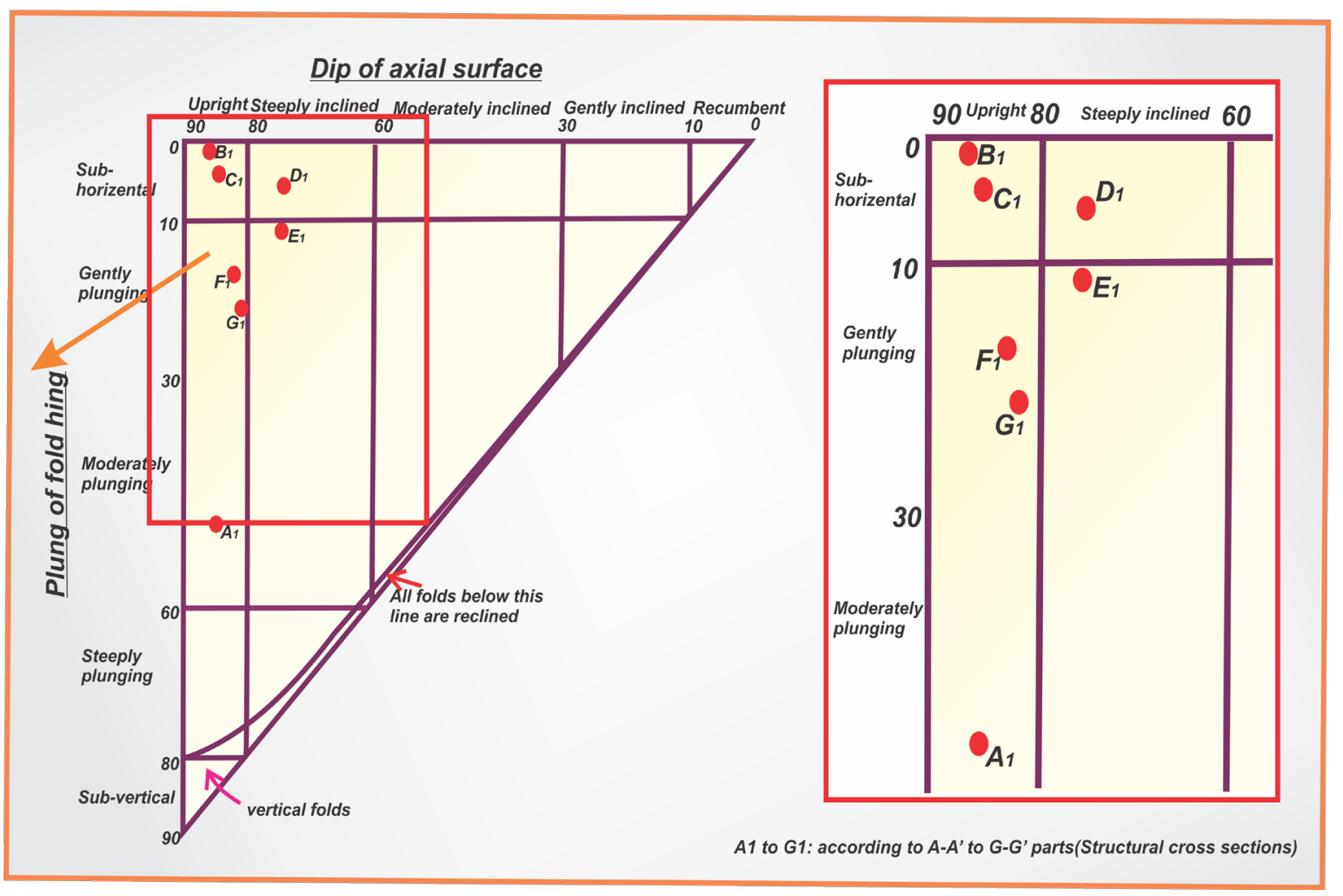

Figure 16. This figure showing the classification for orientation of the Khaftar anticline based on [29].

Some given results such as folding style analysis, how position of salt plug, changes of fold type and main structural changes (rotation of fold axis and $2.5 \mathrm{~km}$ displacement in this anticline) show main changes in the middle parts of the Khaftar anticline. It seems that, these changes have formed by activity of the Nezama bad fault and activity this fault, same as fault zone. 


\section{Acknowledgements}

The authors acknowledge the Department of geology, Islamic Azad University, Science and Research branch, Tehran, Iran for funded this project. In addition, we thank Vice-President for Research in Science and Research branch, Tehran. Thank the National Iranian Oil Company (NIOC) exploration for continuing support this project.

\section{References}

[1] Beydoun, Z.R., Hughes Clark, M.W. and Stoneley, R. (1992) Petroleum in the Zagros Basin. A Late Tertiary Foreland Basin Overprinted onto the Outer Edge of a Vast Hydrocarbon-Rich Palaeozoic-Mesozoic Passive Margin Shelf. American Association of Petroleum Geologists, Memoir, 55, 309-339.

[2] Motiei, H. (1993) Stratigraphy of Zagros. Treatise on the Geology of Iran No. 1. Ministry of Mines and Metals, Geological Survey of Iran, Tehran.

[3] Molnar, M. (2006) Tertiary Development of the Zagros Mountains, Geol 418-Earth History.

[4] Furst, M. (1976) Tektonik und Diapirismus der östlichenZagrosketten. Zeitschrift der Deutschen Geologischen Gesellschaft, 127, 183-225.

[5] Arian, M. (2013) Physiographic-Tectonic Zoning of Iran’s Sedimentary Basins. Open Journal of Geology, 3, $169-177$. http://dx.doi.org/10.4236/ojg.2013.33020

[6] Blance, et al. (2003) Structural Styles in the Zagros simple Folded Zone, Iran. Journal of the Geological Society, 160, 401-412. http://dx.doi.org/10.1144/0016-764902-110

[7] Burberry, Caroline M., Cosgrove, John, W. and Liu, J.-G. (2008) Spatial Arrangement of Fold Types in the Zagros Simply Folded Belt, Iran, Indicated by Landform Morphology and Drainage Pattern Characteristics.

[8] Alavi, M. (2004) Regional Stratigraphy of the Zagros Fold-Thrust Belt of Iran and Its Proforeland Evolution. American Journal of Science, 304, 1-20. http://dx.doi.org/10.2475/ajs.304.1.1

[9] Bahroudi, A. and Koyi, H. (2003) Effect of Ductile and Frictional Décollements on Style of Extension. Journal of Structural Geology, 25, 1401-1423. http://dx.doi.org/10.1016/S0191-8141(02)00201-8

[10] Falcon, N. (1974) Southern Iran: Zagros Mountains. In: Spencer, A., Ed., Mesozoic-Cenozoic Orogenic Belts, Geological Society of London, Special Publication 4, London, 199-211.

[11] Setchell, C.M., Cosgrove, J.W. and Liu, J.-G. (2007) The Distribution of Fold Types in the Zagros Simply Folded Belt, Imperial College London, Iran (Map Scale 1:100,000).

[12] Sherkati, S. and Letouzey, J. (2004) Variation of Structural Style and Basin Evolution in the Central Zagros (Izeh Zone and Dezful Embayment), Iran. Marine and Petroleum Geology, 21, 535-554.

[13] Sherkati, S., Molinaro, M., Frizon de Lamotte, D. and Lettouzey, J. (2005) Detachment Folding in the Central Eastern Zagros Fold-Belt (Iran): Salt Mobility, Multiple Detachments and Late Basement Control. Journal of Structural Geology, 27, 1680-1696. http://dx.doi.org/10.1016/j.jsg.2005.05.010

[14] Letouzey, J. and Sherkati, S. (2004) Salt Movement, Tectonic Events, and Structural Style in the Central Zagros Fold and Thrust Belt (Iran). Salt Sediments Hydrocarbon Prospectivity, 24th Annual GCSSEP, Foundation, Interactions and Bob F. Perkins Research Conference, Houston, 5-8 December 2004.

[15] Alavi, M. (2007) Structures of the Zagros Fold-Thrust Belt in Iran. American Journal of Science, 307, 1064-1095. http://dx.doi.org/10.2475/09.2007.02

[16] Barzegar, F. (1994) Basement Fault Mapping of ZagrosFolded Belt (S. W. Iran) Based on Space-Born Remotely Sensed Data. Proceeding of the 10th Thematic Conference on Geologic Remote Sensing: Exploration, Environment and Engineering, 10, 455-466.

[17] McQuillan, H. (1991) The Role of Basement Tectonics in the Control of Sedimentary Facies, Structural Patterns and Salt Plug Emplacements in the Zagros Fold Belt of Southwest Iran. Journal of Southeast Asian Earth Sciences, 5, 453463, Printed in Great Britain.

[18] Talbot, C.J. and Alavi, M. (1996) The Past of a Future Syntaxis across the Zagros. In: Alsop, G.I., Blundell, D.J. and Davison, I., Eds., Salt Tectonics, Vol.100, Geological Society of London, Special Publication, London, 89-109.

[19] O’Brien, C.A.E. (1950) Tectonic Problems of the Oil Field Belt of Southwest Iran. Proceedings of 18th International of Geological Congress, Great Britain, Part 6, 45-58.

[20] Jamison, W.R. (1987) Geometric Analysis of Fold Development in Over-Thrust Terrenes. Journal of Structural Geology, 9, 207-219. http://dx.doi.org/10.1016/0191-8141(87)90026-5

[21] Mitra, S. (2002) Fold-Accommodation Faults. Bulletin of the American Association of Petroleum Geologists, 86, 671- 
693.

[22] Mitra, S. (2003) A Unified Kinematic Model for the Evolution of Detachment Folds. Journal of Structural Geology, 25, 1659-1673. http://dx.doi.org/10.1016/S0191-8141(02)00198-0

[23] Suppe, J. (1985) Geometry and Kinematics of Fault-Bend Folding. American Journal of Science, 283, 684-721.

[24] NIOC (2001) Geological Map of Iran, Kushk, 1:100,000.

[25] Hessami, K., Koyi, H.A. and Talbot, C.J. (2001) The Significance of Strike-Slip Faulting in the Basement of the Zagros Sold and Thrust Belt. Journal of Petroleum Geology, 24, 5-28.

[26] Shamshiri, M. (2001) The Exploration Project of Fars Region.

[27] Twiss, R.J. and Moores, E.M. (1992) Structural Geology. W.H. Freeman and Company, New York, 224-230.

[28] Ragan, D.M. (1985) Structural Geology, an Introduction to Geometrical Techniques. 3rd Edition, John Wiley \& Sons, Inc., Hoboken, 210-215.

[29] Ramsay, J.G. (1967) Folding and Fracturing of Rocks. McGraw-Hill, New York.

[30] Rickard, M.J. (1971) A Classification Diagram for Fold Orientation.

[31] Colman-Sadd, S.P. (1978) Fold Development in Zagros Simply Folded Belt, Southwest Iran. Bulletin of the American Association of Petroleum Geologists, 62, 984-1003.

[32] Ala, M.A. (1974) Salt Diapirism in Southern Iran. Bulletin of the American Association of Petroleum Geologists, 58, 1758-1770.

[33] Kent, P.E. (1970) The Salt of the Persian Gulf Region. Transactions of the Leicester Literary \& Philosophical Society, 64, 56-88.

[34] Player, R.A. (1969) The Hormuz Salt Plugs of Southern Iran. MS, PhD. Thesis, University of Reading, Reading, 300.

[35] McQuarrie, N. (2004) Crustal Scale Geometry of the Zagros Fold-Thrust Belt, Iran. Journal of Structural Geology, 26, 519-535. http://dx.doi.org/10.1016/j.jsg.2003.08.009

[36] Dehbashi Ghanavati (2009) Geometry of Folding Style Analysis in the Coastal Fars and Effects of Nezamabad Fault in the Structures Region. PhD Thesis of Structural Geology, Science and Research Branch of Tehran, Islamic Azad University, Tehran, 200.

[37] Setudehnia, A. and Perry, J.T. (1965) Geological Map of SE \& SE Fars, Scale 1: 250,000. National Iranian Oil Company, Tehran.

[38] Barzegar, F. (1992) Introducing Firuzabad and Nezamabad Faults. Proceedings of 10th Geosciences Conference, Geological Survey of Iran, Tehran, 15-16 February 1992.

[39] Furst, M. (1990) Strike-Slip Faults and Diapirism of the South-Eastern Zagros Ranges. Proceeding of Symposium on Diapirism, Iran, 2, 149-182.

[40] Nogole-Sadat, M.A.A. and Almasian, M. (1993) Tectonic Map of Iran in 1:1000,000 Scale. Geological Survey of Iran, Tehran.

[41] Yassaghi, A. (2006) Integration of Landsat Imagery Interpretationand Geomagnetic Data on Verification of Deepseatedtransvers Fault Lineaments in SE Zagros. International Journal of Remote Sensing, 27, 1-16.

[42] Alavi, M. (1994) Tectonics of the Zagros Orogenic Belt of Iran: New Data and Interpretations. Tectonophysics, 229, 211-238. http://dx.doi.org/10.1016/0040-1951(94)90030-2

[43] Letouzey, J., Molinaro, M., de Lamotte, D.F. and Letouzey, J. (2005) Detachment Folding in the Central Eastern Zagros Fold-Belt (Iran): Salt Mobility, Multiple Detachments and Late Basement Control. Journal of Structural Geology, 27, 1680-1696. http://dx.doi.org/10.1016/j.jsg.2005.05.010 